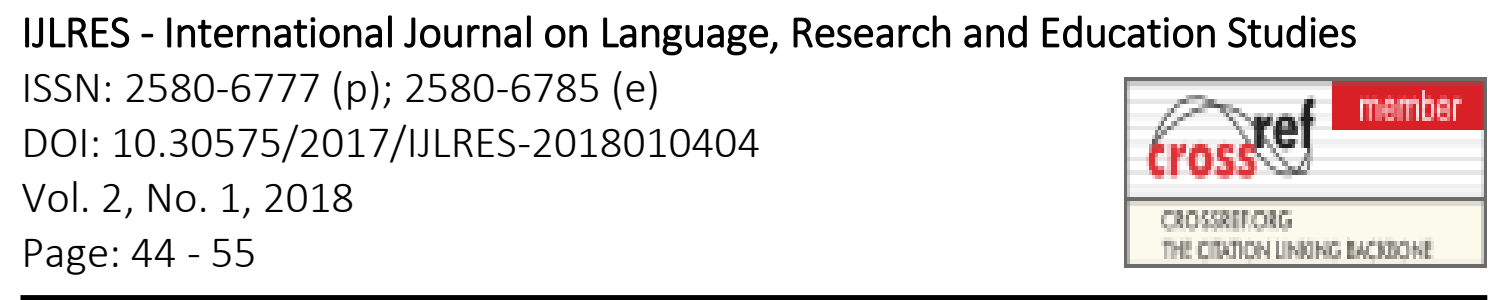

\title{
TEACHERS AND EDUCATION OF CHARACTER INSTILLATION (Research Result at Private Elementary School of Muhammadiyah in Medan)
}

\author{
Amini \\ Faculty of Education and Teachers Training \\ University of Muhammadiyah Sumatera Utara \\ amini_umsu@yahoo.co.id
}

\begin{abstract}
Teachers are the most important element in the development of character education in elementary school, because it becomes the main foundation for a child. Therefore character education made a continuous process to produce a future human figure rooted in the cultural values of the Indonesian nation. Character education in the current context is very relevant to students to tackle the ongoing moral crisis in our country, including free association, crime against friends, teenage theft, cheating, drug abuse and drugs, pornography, brawls, and others. This is based on the results of research on SDS Muhammadiyah about teacher and character education education. The research methodology was conducted with qualitative descriptive analysis. Data obtained based on interviews, observation, and study documentation with the object of research. The result of the research shows that character education education in SDS Muhammadiyah 29 Medan City is contained in all subjects and outside subjects that are instilled early on by all teachers. Cultivation of character education conducted in all subjects through 3 content, ie general content (PAI, PKn, IPS, IPA, Bahasa Indonesia, Mathematics, Arts and Culture), special content (Kemuhammadiyahan), and Local Content (Malay Arabic / Arabic, English, Computer). Character education model performed outside the subjects through 4 things, namely: religious habituation (religious), discipline exercises, fun activities, and sports activities. Commonalities include (the implementation of Zuhr prayers bertamaaah, dhuha congregation, tadarus Al-Qur'an and memorizing the verses of Al-Qur'an, and culture shake). Discipline includes (the existence of rules and school rules and liaison books every day). Kewiraaan include (Flag ceremony and Hizbul wathan). Exercise includes (physical fitness exercise).
\end{abstract}

Keywords: Teachers, Character Building, Private Elementary School of Muhammadiyah

\section{INTRODUCTION}

Criticism of the educational world that emerged lately in the midst of society is that our education in general in Indonesia has not succeeded in building a character human. In fact, not a few who mention that our education fails because many of our school graduates from elementary school to college, from scholars to professors and who have a brain that is smart but mentally weak and behave immorally. This can happen because the planting of characters that have not been imprinted and not memorable when used to be at the elementary school level. 


\section{TEACHERS AND EDUCATION OF CHARACTER INSTILLATION \\ (Research Result at Private Elementary School of Muhammadiyah in Medan) \\ DOI: 10.30575/2017/IJLRES-2018010404}

Therefore, character education should be instilled since starting from the elementary school level. This can be used as the main foundation for children to continue their education in the future. It is also possible that the elementary students are more easily formed by the teacher's personality so that it will have an impact on his character. If it is formed personality in the elementary school then it will be more character again at the next age. So in the future with the application of character education embedded through integrated curriculum, children will become more disciplined, non-violent, not against teachers, diligent study, happy to help others, respect for parents and teachers, not doing immorality, and others. This is in line with the culture imparted through character education, among others: piety, wisdom, justice, equality, self-esteem, selfconfidence, harmony, independence, caring, harmony, fortitude, creativity, competitive, hard work, tenacity, honor, and exemplary.

Thus, the cultivation of education is very important instilled by the teacher in an integrated at the elementary level, because at this level a child is more easily formed its character. So the teacher is the most important element in the cultivation of character education for a child. For this reason, teacher research and character education in SDS Muhammadiyah 29 in Medan were conducted.

\section{LITARATURE REVIEW}

\section{Meaning and the Urgency of Education of Character}

Character can be conceived as a blend of all human nature that is fixed, so a special sign to distinguish one person with another ${ }^{1}$. The character is who you really are. This restriction implies that the character as an identity possesses a person who is sedentary so that someone or something is different from the others ${ }^{2}$.

At the micro level the character is defined; a) the quality and quantity of reactions to oneself, others, as well as certain situations, b) character, morals, psychological characteristics. As a personality aspect, character is a reflection of the whole personality of a person: mentality, attitude, and behavior ${ }^{3}$. Character is defined as a picture of

${ }_{1}$ Zubaedi, (2011). Desain Pendidikan Karakter; Konsepsi dan Aplikasinya Dalam Lembaga Pendidikan, Jakarta: Kencana. hlm 9

2 Ibid. p 9

${ }^{3}$ Ibid. p 9 
behavior that accentuates the value of right-wrong, good-bad, either explicitly or implicitly

The word character comes from the Greek word, which means "to mark" and focuses, how to apply the value of kindness in the form of action or behavior. Therefore, a person who behaves dishonest, cruel, or greedy is said to be a person of ugly character, while a person who behaves honestly, helps to be said to be a person of noble character. So the term character closely related to personality (personality) of a person. A person can be called a person character if his behavior is in accordance with moral rules ${ }^{5}$.

In Islamic terminology, the definition of character has a closeness of understanding with the notion of morals. The word akhlak comes from the word khalaqa (Arabic) which means temperament, character and customs. According to the etymological approach, the moral approach derives from Arabic plural from the form of mufradnya khuluqun which according to lughah interpreted manners, temperament, behavior or character 6 . Character is the way of thinking and behaving that characterizes each individual to live and work together, both within the scope of family, society, nation and state. A well-characterized individual is an individual who can make decisions and be prepared to account for any consequences of the decisions he makes ${ }^{7}$. On the other hand, character refers to a series of attitudes, behaviors, motivations, and skills ${ }^{8}$.

Character education is character education plus, which involves aspects of knowledge (cognitive), feeling, and action. Without these three aspects, character education will not be effective9. There are a number of cultural values that can be characterized, namely piety, wisdom, justice, equality, self-esteem, self-confidence, harmony, independence, caring, harmony, fortitude, creativity, competitive, hard work, tenacity, honor, discipline and exemplary.

With a systematic and sustained character education, a child will be emotionally intelligent. This emotional intelligence is an important provision in preparing children

\footnotetext{
${ }^{4}$ Alwisol, (2006). Psikologi Kepribadian, Malang, UMM. hlm 8

${ }^{5}$ Zubaedi, (2011). Desain Pendidikan Karakter; Konsepsi dan Aplikasinya Dalam Lembaga Pendidikan, Jakarta: Kencana. $\mathrm{p} 12$

${ }^{6}$ Ma'ruf, Luis, (tt) Al-Munjid, Beirut: al-Maktabah Al-katulikiyah, hlm 1994

7 Suyanto, (2000). Refleksi dan Reformasi Pendidikan di Indonesia Memasuki Millennium Ketiga, Yogyakarta, Adi Cita karya Nusa, p 15

8 Kementerian Pendidikan Nasional, (2010). Panduan Pendidikan Karakter. Jakarta: Kemdiknas. p 12

9 Suyanto, (2000). Refleksi dan Reformasi Pendidikan di Indonesia Memasuki Millennium Ketiga, Yogyakarta, Adi Cita karya Nusa, p 15
} 


\section{TEACHERS AND EDUCATION OF CHARACTER INSTILLATION \\ (Research Result at Private Elementary School of Muhammadiyah in Medan) \\ DOI: 10.30575/2017/IJLRES-2018010404}

for the future, because one will more easily and successfully face all kinds of life challenges, including the challenge of academically successful.

The basis of this character education, should be applied since childhood or commonly called psychologists as golden age, because this age is proven to determine the ability of children in developing their potential. The results showed that about $50 \%$ of adult intelligence variability has occurred when children aged 4 years. The next $30 \%$ increase occurs at the age of 8 , and the remaining $20 \%$ in the middle or end of the second decade. From here, it is fitting for character education starting from within the family, which is the first environment for the child's character growth.

However, for some families, perhaps the systematic character education process above is very difficult, especially for some parents who are stuck in a crowded routine. Therefore, character education should also be given when children enter the school environment, especially since play groups and kindergartens. This is where the role of the teacher, who in Javanese philosophy is called digugu and imitated. Because the teacher is the spearhead in the classroom, which is directly opposite the learner.

Character education aims to form and build the mindset, attitude, and behavior of learners to be a positive person, noble, noble, and responsible. In the context of education, character education is a conscious effort made to form learners into a positive person and morality according to the competency standards of graduates (SKL) so that it can be implemented in everyday life. Character education has three main functions: first, the function of formation and development of potential. second, the repair and reinforcement function, third, the filter function

\section{The Framework of Character Education}

Character education basically includes the development of substance, process, and atmosphere or environment that inspires, encourages, and facilitates a person to develop good habits in everyday life. This habit will arise and develop based on the awareness, belief, sensitivity, and attitudes of the person concerned.

Based on the grand design of the development of kemendiknas psychologically and socially cultural character formation in the individual is a function of the whole potential of human individuals (cognitive, apektif, and psikomotorik) in the context of 
cultural social interaction (in family, school and community) ${ }^{10}$. Configuration of characters in the context of the totality of psychological and social processes can be categorized in liver, thought, sport and kinesthetic, and taste and karsa.

Character education is an effort designed and implemented systematically to assist students in understanding the values of human behavior associated with God Almighty, self, fellow human beings, environment, and nationality embodied in thoughts, attitudes, feelings, words, and deeds based on the norms of religion, law, etiquette, culture, and customs.

Therefore, the values and description of character education are identified as follows:

Table I the Value and Description of Character Education

\begin{tabular}{|c|c|c|}
\hline No. & Velues & Description \\
\hline 1. & Religious & $\begin{array}{l}\text { Attitudes and behaviors that obedient in implementing } \\
\text { religious teachings that are adhered to, tolerant of the } \\
\text { implementation of other religious services, and live in } \\
\text { harmony with followers of other religions. }\end{array}$ \\
\hline 2. & Honest & $\begin{array}{l}\text { Behavior based on an attempt to make himself or herself } \\
\text { trustworthy in words, actions and work. }\end{array}$ \\
\hline 3. & Tolerance & $\begin{array}{l}\text { Attitudes and actions that respect different religious, } \\
\text { ethnic, ethnic, opinion, attitude, and other person's } \\
\text { differences. }\end{array}$ \\
\hline 4. & Discipline & $\begin{array}{l}\text { Behaviors that demonstrate orderly behavior and abide } \\
\text { by various rules and regulations. }\end{array}$ \\
\hline 5. & Hard Work & $\begin{array}{l}\text { Behavior that shows a genuine effort to overcome the } \\
\text { obstacles of learning and duty, and complete the tasks as } \\
\text { well as possible. }\end{array}$ \\
\hline 6. & Creative & $\begin{array}{l}\text { Think and do something to produce new ways or results } \\
\text { from something you already have. }\end{array}$ \\
\hline 7. & Independent & $\begin{array}{l}\text { Attitudes and behaviors that are not easy depend on } \\
\text { others in completing tasks. }\end{array}$ \\
\hline
\end{tabular}

10 Ministry of National Education, (2010). Panduan Pendidikan Karakter. Jakarta: Kemdiknas. 
TEACHERS AND EDUCATION OF CHARACTER INSTILLATION

(Research Result at Private Elementary School of Muhammadiyah in Medan)

DOI: 10.30575/2017/IJLRES-2018010404

\begin{tabular}{|c|c|c|}
\hline 8. & Democratist & $\begin{array}{l}\text { The way of thinking, acting, and acting that judges } \\
\text { equally the rights and obligations of oneself with others. }\end{array}$ \\
\hline 9. & Curiosity & $\begin{array}{l}\text { Attitudes and actions that always strive to know more } \\
\text { deeply and extend from something he learned, seen and } \\
\text { heard. }\end{array}$ \\
\hline 10. & $\begin{array}{l}\text { Spirit of } \\
\text { Nationality }\end{array}$ & $\begin{array}{l}\text { The way of thinking, acting and insight that places the } \\
\text { interests of the nation and the State above the interests of } \\
\text { the self and the group. }\end{array}$ \\
\hline 11. & $\begin{array}{l}\text { Love the } \\
\text { Country }\end{array}$ & $\begin{array}{l}\text { The way of thinking, acting and acting demonstrates } \\
\text { loyalty, awareness, and high appreciation for the } \\
\text { language, the physical, social, cultural, economic and } \\
\text { political environments of the nation. }\end{array}$ \\
\hline 12. & $\begin{array}{l}\text { Appreciate to } \\
\text { Achievement }\end{array}$ & $\begin{array}{l}\text { Attitudes and actions that drive him to produce } \\
\text { something useful for society, and recognize and respect } \\
\text { the success of others. }\end{array}$ \\
\hline 13. & Communicative & $\begin{array}{l}\text { Actions that show the pleasure of talking, getting along, } \\
\text { and working with others. }\end{array}$ \\
\hline 14. & Love of Peace & $\begin{array}{l}\text { Attitudes, speech and actions that cause others to feel } \\
\text { happy and secure for their presence. }\end{array}$ \\
\hline 15. & Like to read & $\begin{array}{l}\text { The habit of taking the time to read the various readings } \\
\text { that give well to him. }\end{array}$ \\
\hline 16. & $\begin{array}{l}\text { Care to } \\
\text { Environment }\end{array}$ & $\begin{array}{l}\text { Attitudes and actions that always try to prevent damage } \\
\text { to the surrounding natural environment and work to } \\
\text { improve it. }\end{array}$ \\
\hline 17. & Social Care & $\begin{array}{l}\text { Attitudes and actions that always want to help others } \\
\text { and people in need. }\end{array}$ \\
\hline 18. & Responsibility & $\begin{array}{l}\text { Attitudes and behavior of a person to carry out his duties } \\
\text { and obligations, which should be done to self, society, } \\
\text { environment, State, and God Almighty. }\end{array}$ \\
\hline
\end{tabular}

Therefore teaching character education requires a special approach because it involves the apective aspect. According to President SBY that character education 
planting must be with examples and concrete example. In school, for example, exemplars must start from a teacher. Teachers should show good example in front of their students, so that it can be an example for their students. Therefore the effort to implement character education needs to be done with holistic approaching that is integrating character development into every aspect of school life.

Meanwhile, the role of educational institutions or schools in the implementation of character education can be through four steps;

1) Gather teachers, parents, and students together identify and define the elements of character they want.

2) Provide training for teachers on integrating character education into school life and culture.

3) Cooperate with parents and the community so that students can hear that character behavior is important for success in school and life.

4) Provide opportunities for principals, teachers, parents, and communities to model social and moral behavior.

\section{METHODOLOGY}

\section{Research Design and Procedure}

The research method used in this research is descriptive with qualitative analysis, the purpose is to describe or describe the condition of the field, the actual data by still paying attention to the authenticity of the data as a form of social fact. This study also aims to describe systematically the facts or characteristics of a particular population or field in a factual and accurate. The use of this qualitative approach with several considerations include: 1) technical qualitative analysis easier when faced with double reality, 2) this technique presents directly the nature of the relationship between the researcher with the respondent, so it is considered more sensitive and more able to adapt to a lot of sharpening influence together against the value patterns encountered.

\section{Data collection technique}

Data collection is a very important step in this research, because the main purpose of a study is to collect data. According to Cathrine Marshall, Gretchen B. Rosman that in qualitative research, data collection is done on natural natural 
setting conditions) primary data sources, and data collection techniques are more on participatory observation, in-depth interviews and documentation. Any important data or information will be traced to completion until the correctness of the data is completely valid. Therefore, in data collection it is possible to involve many parties outside the existing subjects in SDS Muhammadiyah 29. Thus the data collection techniques conducted in this study is by interview, observation, and documentation study. Informants taken in this research are principals, teachers, and employees SDS Muhammadiyah 29 Medan City.

The location of the research is SDS Muhammadiyah 29 Kota Medan which is located at Jl. teak No. 60 seimencirim Sunggalatan Sunggal Deli Serdang District of North Sumatra Province

\section{FINDINGS AND DISCUSSION}

\section{General Findings}

Based on the results of observation, interview and documentation study on the object of research that is in SDS Muhammadiyah 29 Medan City found general findings, which includes vision, mission and objectives SDS Muhammadiyah 29.

Based on documentary study from SDS Muhammadiyah 29 found the vision, mission and objectives of the school are as follows:

Vision SDS Muhammadiyah 29 is a Superior Educational Institution, in Science and Skill, and Contextual and Islamic-minded as Character.

The mission of SDS Muhammadiyah 29 is as follows:

1 Implementing effective learning and guidance in accordance with the National Curriculum and Muhammadiyah.

2 Implementing Optimal Learning with PAIKEM Method.

3 Emphasizing Beliefs of Faith through the Experience of the Doctrine of Religion.

4 Establish creativity and scientific, artistic and sporting achievements as well as organizational and societal skills imbued with zeal to tauhidan.

5 Organizing Islamic da'wah activities, amar ma'ruf nahi munkar as an integral part of the goals of Muhammadiyah University. 
6 Increase the spirit of learning in order to intellectual, emotional and spiritual intellectual.

7 Building a Trusted School Culture in the Community.

8 Creating a Conducive Environment Supports Learning

While the goal is the realization of Muslim humans who are pious, noble, capable, believe in yourself, love the homeland, and useful for society and country.

And more specifically the purpose of Basic Education is to lay the foundation of intelligence, knowledge, personality, noble character, as well as independent living skills and follow education further. Referring to the purpose of basic education, the purpose of Private Elementary School Muhammadiyah 29 are:

1) Can practice the teachings of religion results of learning and habituation activities.

2) Achieving academic and non academic achievement.

3) Mastering the basics of science and technology as a provision to continue to a higher school

4) Being a school and activator in the surrounding community

5) Be a trustworthy school to pursue a child's future.

\section{Specific Findings}

Therefore, based on the results of observation, interview and documentation study on the object of research entitled teacher and the cultivation of education karakakter on SDS Muhammadiyah 29 in Medan found the results achieved are as follows:

\section{Identify the planting of Character Education through an Integrated Curriculum in All Subjects.}

After conducting research on the object of research through documentary study SDS Muhammadiyah 29 curriculum in carrying out character education through an integrated curriculum on all subjects in the class are found through 3 cargo. This is in line with the proposed Zubaedi in Character Education Design, 2011: 271 that macro, character education can be integrated in intrakurikuler and kokurikuler activities. The planning and implementation of character education is conducted by principals, teachers, and education personnel (counselors) together as a community of educators applied into the curriculum through: 1) self-development programs, 2) integration into 
all subjects, 3) integration into curricular and extracurricular activities, 4) habituate.

Therefore, according to Zubaedi one of the character education education through integration into all subjects. This is what researchers found in SDS Muhammadiyah that the implementation of character education through the 3 content of learning is as follows:

\section{Character Education Through Public Upload Subjects}

The practice of character education in schools is not only the responsibility of the teachers of Religious subjects or PKN. During this time there is the impression that other subjects only teach knowledge in accordance with the field of science, technology and art. Whereas the character education process should be integrated in all subjects. Character education is basically attached to each subject because each subject basically has character values that must be passed or achieved by students. It's just that, some of the things that do not realize that there are values that can shape the character of students ${ }^{11}$.

\section{Character Education Through Local Subject Subjects}

Local Content of Private Elementary School Muhammadiyah 29 Kota Medan.

1. English

- Introduce English as the language of international communication

- Equip students to face demands in order to welcome the era of globalization.

2. Arabic

- Introduce Arabic as the language of the Qur'an

- Introduce Arabic as the language of communication.

- Introduce Malay Arabic Scripts to students.

3. Computer

- Introduce informatics technology to learners

11 Zubaedi, (2011). Desain Pendidikan Karakter; Konsepsi dan Aplikasinya Dalam Lembaga Pendidikan, Jakarta: Kencana. hlm 273 


\section{Identify the planting of Character Education through an Integrated Curriculum outside the Subject.}

After doing research on the object of research through observation and interview (interview) on SDS Muhammadiyah 29 in carrying out character education through integrated curriculum on habituation activities found through some habituation activities, among others, as follows:

1. Religious Discussion

Religious activity is done through 4 habits:

a. Zuhr prayers in congregation.

b. Prayers dhuha congregation

c. Tadarus Al-Qur'an and Hapalan verses of the Qur'an

d. Culture shook

2. Discipline Practice

According to the principal's mother this is done so that they are more accustomed to discipline, and they will crack down on students firmly against anyone who violates the rules and order of the school. They mentioned that he never discriminated against all his students in SDS Muhammadiyah 29.

3. Activities of Love to Country

This activity is done through two things: Scout / Hizbul Wathon (HW) and Flag Ceremony. According to the interview of the researcher with Mrs. Wagisah, S.Pd.I as a teacher of kemuhammadiyahan, that he mentioned them every Friday and Saturday wearing Hizbul Wathan's clothes and every Monday and certain days doing flag ceremony activities. This they alakuakan that they are accustomed in defending the NKRI as our beloved country.

4. Sport Activities

Based on the results of field observations of researchers on SDS Muhammadiyah 29 as a research object found they do sports activities for all students both men and women to do gymnastics every Friday.

\section{CONCLUSION}

Based on the results of research through observation, interview and documentation study on the object of research on teacher and character education education at SDS Muhammadiyah 29 in Medan by the teacher can be 
concluded:

1. That the character education planting through an integrated curriculum conducted by SDS Muhammadiyah 29 in Medan is contained in all subjects and outside subjects inculcated early by all teachers.

2. Cultivation of character education conducted in all subjects through 3 contents, namely general content (PAI, PKn, IPS, IPA, Bahasa Indonesia, Mathematics, Arts and Culture), special content (Kemuhammadiyahan), and Local Content Arabic Malay / Arabic, English, Computers)

3. Cultivation of character education conducted outside the subjects through 4 things, namely: religious habituation (religiousity), discipline exercises, fun activities, and sports activities. Commonalities include (the implementation of Zuhr prayers bertamaaah, dhuha congregation, tadarus Al-Qur'an and memorizing the verses of Al-Qur'an, and culture shake). Discipline includes (the existence of rules and school rules and liaison books every day). Kewiraaan include (Flag ceremony and Hizbul wathan). Exercise includes (physical fitness exercise).

4. The advantages of integrated curriculum owned and implemented by SDS Muhammadiyah have several advantages, such as: a) The curriculum applied by SDS Muhammadiyah for all these subjects has been designed as possible based on the national education curriculum and Al-Islam Kemuhammadiyahan curriculum as a whole.

\section{BIBILIOGRAPHY}

Alwisol, (2006). Psikologi Kepribadian, Malang: UMM.

Kementerian Pendidikan Nasional, (2010). Panduan Pendidikan Karakter. Jakarta: Kemdiknas.

Ma'ruf, L, (tt) Al-Munjid, Beirut: al-Maktabah Al-katulikiyah

Sugiyono,(2009). Metode Penelitian Pendidikan, Bandung: Alfabeta.

Suyanto, (2000). Refleksi dan Reformasi Pendidikan di Indonesia Memasuki Millennium Ketiga, Yogyakarta: Adi Cita karya Nusa,

Zubaedi, (2011). Desain Pendidikan Karakter; Konsepsi dan Aplikasinya Dalam Lembaga Pendidikan, Jakarta: Kencana. 